Abstracta Iranica Abstracta Iranica

Revue bibliographique pour le domaine irano-aryen

Volume 25 | 2004

Comptes rendus des publications de 2002

\title{
«Safavid blue and white bowls and the Chinese connection ». Iran, vol. 40, (2002), pp. 257-263.
}

\section{Monik Kervran}

\section{(2) OpenEdition}

1 Journals

\section{Édition électronique}

URL : http://journals.openedition.org/abstractairanica/4759

DOI : 10.4000/abstractairanica.4759

ISSN : 1961-960X

Éditeur :

CNRS (UMR 7528 Mondes iraniens et indiens), Éditions de l'IFRI

\section{Édition imprimée}

Date de publication : 15 mai 2004

ISSN : 0240-8910

\section{Référence électronique}

Monik Kervran, « «Safavid blue and white bowls and the Chinese connection ». Iran, vol. 40, (2002), pp. 257-263. », Abstracta Iranica [En ligne], Volume 25 | 2004, document 204, mis en ligne le 15 mars 2006, consulté le 25 septembre 2020. URL : http://journals.openedition.org/abstractairanica/4759; DOI https://doi.org/10.4000/abstractairanica.4759

Ce document a été généré automatiquement le 25 septembre 2020.

Tous droits réservés 


\section{«Safavid blue and white bowls and the Chinese connection ". Iran, vol. 40, (2002), pp. 257-263.}

\section{Monik Kervran}

1 Après que les Perses, aidés par la flotte anglaise, aient chassé les Portugais d'Hormuz en 1623, les Hollandais profitèrent de l'ouverture de cette voie commerciale et firent de Bandar Abbas une escale pour leurs navires marchands, y négociant les porcelaines chinoises en Iran tout en les utilisant comme ballast. La vaisselle de porcelaine bleue et blanche fut aussitôt copiée par les céramistes persans et on a ainsi de nombreux bols safavides directement inspirés de modèles en Kraak, porcelaines qu'on peut dater, sur des arguments qu'expose Y. Crowe, d'avant le milieu du $17^{\mathrm{e}} \mathrm{s}$., dernière partie du règne de Šāh 'Abbās et règne de son successeur Šāh Șafĩ I.

\section{INDEX}

Thèmes : 5.1. Monde iranophone

\section{AUTEURS}

MONIK KERVRAN

CNRS - Paris 